\title{
Cloning of Phospholipase D from Grape Berry and Its Expression under Heat Acclimation
}

\author{
Si-Bao Wan ${ }^{1, \#}$, Wei Wang1, ${ }^{1,}$, Peng-Fei Wen ${ }^{1,2}$, Jian-Ye Chen ${ }^{1,3}$, Wei-Fu Kong ${ }^{1}$, Qiu-Hong Pan ${ }^{1}$, \\ Ji-Cheng Zhan ${ }^{1}$, Li Tian ${ }^{1}$, Hong-Tao Liu ${ }^{1}$ and Wei-Dong Huang,* \\ ${ }^{1}$ College of Food Science \& Nutritional Engineering, China Agricultural University, Beijing 100083, China \\ ${ }^{2}$ College of Horticulture, ShanXi Agricultural University, Taigu, ShanXi 030801, China \\ ${ }^{3}$ Guangdong Key Laboratory for Postharvest Science, College of Horticulture, South China Agricultural University, \\ Guangzhou, GuangDong 510642, China
}

Received 18 October 2006, Accepted 16 March 2007

To investigate whether phospholipase D (PLD, EC 3.1.4.4) plays a role in adaptive response of post-harvest fruit to environment, a $P L D$ gene was firstly cloned from grape berry (Vitis Vinifera L. cv. Chardonnay) using RT-PCR and 3 '- and 5'-RACE. The deduced amino acid sequence (809 residues) showed $84.7 \%$ identity with that of PLD from Ricinus communis. The secondary structures of this protein showed the characteristic $\mathrm{C} 2$ domain and two active sites of a phospholipid-metabolizing enzyme. The PLD activity and its expression in response to heat acclimation were then assayed. The results indicated PLD was significantly activated at enzyme activity, as well as accumulation of PLD mRNA and synthesis of new PLD protein during the early of heat acclimation, primary suggesting that the grape berry PLD may be involved in the heat response in post-harvest grape berry. This work offers an important basis for further investigating the mechanism of post-harvest fruit adaptation to environmental stresses.

Sequence data from this article have been deposited at GenBank under accession number DQ333882

\begin{abstract}
Abbreviations: CTAB, cetyltrimethyl ammonium bromide; DEPC, diethylpyrocarbonate; EDTA, ethylene diamine tetraacetic acid; Hsp, heat shock protein; Mes, 2-(N-morpholino)ethane sulfonic acid; PA, phosphatidic acid; $\mathrm{PIP}_{2}$, phosphatidylinositol 4,5-bisphosphate; PLC, phospholipase C; PLD, phospholipase D; RACE, rapid amplification of cDNA ends; RT-PCR, reverse transcription-polymerase chain reaction; SDS, sodium dodecyl sulfate; Tris, tris (hydroxymethyl)-amino methane.
\end{abstract}

"These authors contributed equally to this work.

*To whom correspondence should be addressed. Tel: 86-10-6273-7535; Fax: 86-10-6273-7553

E-mail: huanggwd@263.net
Keywords: Cloning, Gene expression, Grape berry, Heat acclimation, Phospholipase D

\section{Introduction}

Plants are often subjected to biotic and abiotic stresses during their growth and development. High temperature is one of the major environmental factors that affect plants growth and productivity (Levitt, 1980; Frova, 2000). Among the various strategies developed by higher plants to cope with high temperature, heat tolerance is the most important one (Srikanthbabu et al., 2002; Sung et al., 2003). In resent years, much evidence supports that a series of heat shock proteins (HSPs) will be induced to express and the amount of salicylic acid will be elevated in plants under heat conditions (Larkindale et al., 2004; Zhang et al., 2005; Howarth et al., 2006; Liu et al., 2006; Pan et al., 2006; Wang L. et al., 2006). On the other hand, the physical state of cell membranes is highly sensitive to heat stress (Wang et al., 2004), and the components of membranes, such as phosphatidic acid, lysophospholipids and free fatty acids, have been found to participate in the temperature stresses (Wang, 2004). Our previous research has showed that a membrane-associated enzyme, $\mathrm{PIP}_{2}$-specific phospholipase $\mathrm{C}$ was activated by heat acclimation and involved in the development of thermotolerance in pea leaves (Liu et al., 2006). So, it is interesting to determine the role that D-type of plant phospholipases plays in response to heat acclimation.

Phospholipase D (PLD, EC 3.1.4.4) is another lipiddegrading enzyme that hydrolyzes phospholipids at the terminal phosphoesteric bond, generating phosphatidic acid and free head groups (Wang, 1999). The gene of the enzyme was first cloned from castor bean (Wang et al., 1994). Since 
then, PLDs have been cloned from many plant organisms, such as Arabidopsis (Dyer et al., 1995), tobacco (Gardiner et al., 2001) and tomato (Pinhero et al., 2003), though most of them were cloned from nutritive organs. Little was studied in fruit such as grape berry. And now numerous reports showed that PLDs and their product, phosphatidic acid, participate in plant responses to environmental stresses, including wounding (Ryu et al., 1996; Wang et al., 2000), chilling (Pinhero et al., 1998; Ruelland et al., 2002), freezing (Li et al., 2004) and water deficit (Munnik et al., 2000; Sang et al., 2001). But the role of PLD in response to heat stress remains essentially unclear.

Here, we reported the $P L D$ gene cloning from grape berry and the changes of PLD activity and its expression at transcriptional and translational levels in response to heat acclimation.

\section{Materials and Methods}

Materials and treatments. Grape berries (Vitis vinifera L. cv. Chardonnary) were harvested from a vineyard in the western suburbs of Beijing at the state of ripeness (about 100th day after full bloom). The freshly harvested berries were selected on the basis of similar size and the absence of physical injuries or infections. The treatments were performed according to Beruter and Studer (1995) with some modifications. The equilibrium buffer contained $50 \mathrm{mM}$ Mes-Tris ( $\mathrm{pH}$ 5.5), $1 \mathrm{mM}$ EDTA, $5 \mathrm{mM}$ ascorbic acid, $5 \mathrm{mM}$ $\mathrm{CaCl}_{2}, 1 \mathrm{mM} \mathrm{MgCl}$ and $200 \mathrm{mM}$ mannitol. The grape berries were separated and immersed in the equilibrium buffer for $30 \mathrm{~min}$. The equilibrated tissues of $30 \mathrm{~g}$ were then placed in a $200 \mathrm{ml}$ Erlenmeyer flask containing $90 \mathrm{ml}$ of the incubation buffer which was preheated to $38^{\circ} \mathrm{C}$. The flasks were gently shaken at $38^{\circ} \mathrm{C}$ for $0,0.5,1,2,4,8$ and $12 \mathrm{~h}$, respectively. The tissue incubated $0 \mathrm{~h}$ was taken as control. After the incubation, the mediums were removed and the tissues were washed three times with double distilled water and then frozen in liquid nitrogen and stored at $-80^{\circ} \mathrm{C}$ until use. Each treatment contained three independent replicates.

Another equilibrated grape berries were immediately immersed in a solution containing an equilibrium buffer with $0.1 \%(\mathrm{v} / \mathrm{v}) 1-$ butanol. A pressure of about $-0.1 \mathrm{MPa}$ for 30 min was used for the 1-butanol infiltration that did not cause the berry any harm. After reversing the pressure, the berries were kept in the media for another $30 \mathrm{~min}$ prior to treatment at $38^{\circ} \mathrm{C}$ for $0,20,40,60$ and 90 min just like above-mentioned.

\section{Cloning of grape berry phospholipase D sequence}

Degenerate oligonucleotides design. Conserved regions of the PLD alpha family were identified by multiple sequence alignment of Arabidopsis (GenBank accession number U36381), castor bean

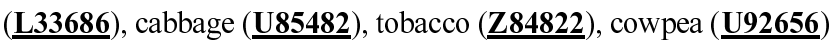
and tomato (AF201661) deposited in GenBank using CLUSTAL program (PCGENE software, Intelligenetics). A pair of degenerate primers were designed and synthesized according to two conserved regions. Forward primer (5'-AAT GCA AAR CAC TTG ATH TAC ATT ACT GGY TGG TC-3') was corresponding to the amino acid sequence NAKHLIYITGW and reverse primer (5'-TCT NGC ACC ATC CAT TGA TCT CTG GTT KAT GTT-3') corresponding to the amino acid sequence NINQRSMDGAR.

RNA extraction and RT-PCR. Total RNA was isolated from grape berry using the method described by Wen et al. (2005). Total RNA samples were then DNase-treated with an RNase-free DNase (TaKaRa) prior to RT-PCR, to remove any contaminating genomic DNA. First-stand cDNA was synthesized in a $20 \mu \mathrm{l}$ reaction mixture with the Reverse Transcription System A3500 (Promega) according to the protocol provided by the manufacturer, using $1 \mu \mathrm{g}$ total RNA isolated from grape berries. One microlitre of frist-strand product was used for PCR reaction in a total volume of $50 \mu \mathrm{l}$ with $20 \mathrm{mM}$ Tris- $\mathrm{HCl}, \mathrm{pH} 8.3,100 \mathrm{mM} \mathrm{KCl}, 5 \mathrm{mM} \mathrm{MgCl}, 25 \mathrm{mM}$ dNTP, 5 units of Taq DNA polymerase (TaKaRa) and 50 pmol of each degenerate primer. PCR was carried out using a GeneAmp PTC-100 cycler with an initial heat action step at $94^{\circ} \mathrm{C}$ for $10 \mathrm{~min}$, and amplifications were achieved through 40 cycles at $94^{\circ} \mathrm{C}$ for $30 \mathrm{~s}, 55^{\circ} \mathrm{C}$ for $60 \mathrm{~s}$, and $72^{\circ} \mathrm{C}$ for $90 \mathrm{~s}$. A final extension reaction was carried out for $10 \mathrm{~min}$ at $72^{\circ} \mathrm{C}$. Negative controls for both cDNA synthesis and PCR were always included. The amplified product of approximately $1.4 \mathrm{~kb}$ was purified and cloned in pGEMT Easy vector (Promega), and transformed into E.coli Competent Cells Top10 (Tiangen). Based on the color reaction using $\mathrm{X}$ galIPTG system and PCR identification, the positive clones were picked out and sequenced by ABI 377 Sequencer (Perkin-Elmer). The sequence of fragment was used to design gene-specific primers of 3'- and 5'- rapid amplification of cDNA ends (RACE).

RACE-PCR of grape berry $P L D$ and cloning of full length cDNA. Full-length grape PLD cDNA was obtained by 3'- and 5'RACE using the SMART ${ }^{\mathrm{TM}}$ RACE cDNA amplification kit (Clontech, USA). Two grape $P L D$-specific primers (5'-GAT TGA GGC AGG GGA GAA GTT CAG TGT TTA T-3') and (5'-GTT CGA TCA TCC CAA ACA AGC ATT AGA ACC C-3') were designed and synthesized for 3'- and 5'- RACE-PCR, respectively. The 3'-RACE Ready cDNA was synthesized using $1 \mu \mathrm{g}$ of total RNA and the 3'-CDS prime. The 5'-RACE Ready cDNA was synthesized using the 5'-CDS primer and BD SMART II ${ }^{\mathrm{TM}}$ A Oligonucleotide. PCR was carried out using the BD Advantage ${ }^{\mathrm{TM}} 2$ Polymerase Mix provided in this kit with an initial heat action step at $94^{\circ} \mathrm{C}$ for $10 \mathrm{~min}$, and amplifications were achieved through 40 cycles at $94^{\circ} \mathrm{C}$ for $30 \mathrm{~s}, 58^{\circ} \mathrm{C}$ for $60 \mathrm{~s}$, and $72^{\circ} \mathrm{C}$ for $90 \mathrm{~s}$. A final extension reaction was carried out for $10 \mathrm{~min}$ at $72^{\circ} \mathrm{C}$. Negative controls for both cDNA synthesis and PCR were always included. The 3'- and 5'- RACE PCR products were cloned and sequenced as described above. The sequences of both strands were compiled and analyzed for an open reading frame. An open reading frame of 2430 nucleotides was uncovered resulting in a predicted protein length of 809 amino acids.

DNA extraction and southern blot analysis. $3 \mathrm{~g}$ grape berries were crushed in liquid nitrogen and total DNA was extracted by the CTAB method (Rogers and Bendich, 1994), and treated with Proteinase $\mathrm{K}$ and Ribonuclease $\mathrm{H}$ (TaKaRa) to remove contaminating proteins and RNA, respectively. Genomic DNA (30 $\mu \mathrm{g} /$ sample) from grape berries was digested over night at $37^{\circ} \mathrm{C}$ with EcoRI and $X b a \mathrm{I}$, respectively, which did not cut within the full-length cDNA 
of grape $P L D$. The digested DNA was separated by electrophoresis on a $0.8 \%(\mathrm{wt} / \mathrm{v})$ agarose gel and transferred onto a positively charged Hybond- $\mathrm{N}^{+}$nylon membrane (Amersham Pharmacia). The membrane was hybridized with a $\left[\alpha-{ }^{32} \mathrm{P}\right] \mathrm{dCTP}$-labeled (Random Primed DNA Labeling Kit, TaKaRa) PCR-amplified PLD cDNA probe over night. The probe was composed of $1431 \mathrm{bp}$ coding sequence in which there are the forward primer 5'-ATTGTTGTGGT GGACAGCGAG-3' and the reverse primer 5'-CTAAGTTGTGAG GATTGGAGG-3'. The hybridized membrane was washed twice with $2 \times \mathrm{SSC}$ and $0.1 \%(\mathrm{wt} / \mathrm{v}) \mathrm{SDS}$ for $5 \mathrm{~min}$ at room temperature, followed by a washing with $0.1 \times \mathrm{SSC}$ and $0.1 \%(\mathrm{wt} / \mathrm{v})$ SDS for $15 \mathrm{~min}$ at $65^{\circ} \mathrm{C}$, and exposed to an X-ray film (Kodak, Japan) for 3 days at $-80^{\circ} \mathrm{C}$ to detect the Hybridizing bands.

Protein extraction and assay of PLD activity. Total proteins were extracted according to the method of Famiani et al. (2000) with minor modifications. The extraction buffer consisted of $50 \mathrm{mM}$ Tris- $\mathrm{HCl}$ (pH 8.9), $250 \mathrm{mM}$ sucrose, $2 \%(\mathrm{wt} / \mathrm{v})$ SDS or $1 \%(\mathrm{v} / \mathrm{v})$ Triton-X100, $5 \mathrm{mM}$ ascorbic acid, $5 \mathrm{mM}$ EDTA, $1 \mathrm{mM}$ PMSF, $2 \mathrm{mM}$ DTT, $14 \mathrm{mM} \beta$-mercaptoethanol and $0.15 \%$ (wt/v) PVP. Tissue samples $(1.0 \mathrm{~g})$ were homogenized in $2 \mathrm{ml}$ extraction buffer, and the $\mathrm{pH}$ value of the homogenate was adjusted to approximately 7.0 by the addition of Tris base before centrifugation. The resultant supernatant was collected as the total protein and the concentration was determined by the method of Bradford (1976) using bovine albumin (BSA) as the standard.

PLD activity was assayed by using L-3-Phosphatidyl[N-methyl${ }^{3} \mathrm{H}$ ]choline, 1,2-dipalmitoyl (Amersham, TRK673) as substrate. The substrate preparation, reaction conditions, and product separation were based on previously described procedures (Wang et al., 1993) with the following changes: $92.5 \mathrm{KBq}$ of radioactive PC (3.03 TBq/ mmol), was mixed with 20 pmol of cold PC (egg yolk; Sigma) in chloroform, and the mixture was dried under a stream of $\mathrm{N}_{2}$. The lipid was then emulsified in $1 \mathrm{ml}$ of $\mathrm{H}_{2} \mathrm{O}$ by sonication at room temperature. A standard enzyme assay mixture contained $100 \mathrm{mM}$ Mes/Tris ( $\mathrm{pH} \mathrm{6.5),} 25 \mathrm{mM} \mathrm{CaCl}_{2}, 20 \mu$ of prepared substrate $(0.4$ pmol), and 2-10 $\mu \mathrm{g}$ of extracted protein in a total volume of $200 \mu \mathrm{l}$. The reaction was performed for $30 \mathrm{~min}$ at $30^{\circ} \mathrm{C}$ in a shaking water bath and stopped by addition of $1 \mathrm{ml}$ of $2: 1(\mathrm{v} / \mathrm{v})$ chloroform : methanol, after which $100 \mu \mathrm{l}$ of $2 \mathrm{M} \mathrm{KCl}$ was added to enhance the phase separation. After vortexing and centrifugation at $12,000 \times g$ for $5 \mathrm{~min}$, a $200 \mu \mathrm{l}$ aliquot of the aqueous phase was mixed with 3 $\mathrm{ml}$ of scintillation fluid, and the release of ${ }^{3} \mathrm{H}$-choline was measured by scintillation counting.

Western blot analyses for PLD and HSP73. Extracted proteins separation was performed using SDS-PAGE in 10\% polyacrylamide gels as described by Laemmli (1970). The total proteins $(10 \mu \mathrm{g})$ were loaded per well. Here, it should be noted that these immunoblotting analyses were based on the same amount of loading proteins in each sample. After electrophoresis, the proteins were elector-transferred to nitrocellulose membranes $(0.45 \mu \mathrm{m}$, Amersham Life Science) using a transfer apparatus (Bio-Rad) technique described by Isla et al. (1998). For protein gel blot analysis, immunological detection of proteins on the NC membrane was carried out using a primary polyclonal PLD $\alpha 1$ antibody (kindly provided by Dr. Wang Xuemin) in a 1/3000 dilution or antibody against HSP73 (Stressgen Conpany, Victoria, BC,
Canada) in a $1 / 1000$ dilution at $25^{\circ} \mathrm{C}$ with an alkaline phosphatase conjugated anti-rabbit IgG antibody from a goat (1/800 dilution) as a secondary antibody. The membrane was stained with $10 \mathrm{ml}$ of 5 bromo-4-chloro-3-indolyl phosphate/niro blue terazolium (BCIP/ NBT) in the dark and the reaction terminated by addition of double distilled water. The intensity of iummunobloting signal was determined by densitometer.

RT-PCR analysis for PLD. The mRNA expression patterns of $P L D$ were examined by quantitative reverse transcription polymerase chain reaction. Meanwhile, the RT-PCR amplification for the house-keeping gene (actinl) was used as an internal control. According to the published sequence of grape Actin1 (GenBank accession no. $\underline{\mathbf{A Y 6 8 0 7 0 1}}$ ) and the sequence described in this study, two pairs of oligonucleotide primers were designed to amplify the cDNA clones that had been selected for expression analysis. Genespecific primers for $P L D$ (forward: 5'-GAAATCGGGAGGTCAA GA AGAG-3'; reverse: 5'-CTAAGTTGTGAGGATTGGAGG-3') and Actinl (forward: 5'-GATTCTGGTGATGGTGTGAGT-3'; reverse: 5'-GACAATTTCCCTTAGCAG-3') were used in RT-PCR. The expected sizes of the PCR products were $560 \mathrm{bp}$ and $168 \mathrm{bp}$. For RT-PCR, the total RNA was isolated and the first-stand cDNA was synthesized using the Reverse Transcription System A3500 (Promega) as described above. One microlitre of frist-strand solution was used for PCR reaction in a total volume of $50 \mu \mathrm{l}$ with $20 \mathrm{mM}$ Tris-HCl, pH 8.3, $100 \mathrm{mM} \mathrm{KCl,} 5 \mathrm{mM} \mathrm{MgCl} 2,2.5 \mathrm{mM}$ dNTP, 5 units of Taq DNA polymerase (TaKaRa) and $10 \mathrm{pmol}$ of each primer. PCR was carried out with an initial heat action step at $94^{\circ} \mathrm{C}$ for $10 \mathrm{~min}$, and amplifications were achieved through 35 cycles at $94^{\circ} \mathrm{C}$ for $30 \mathrm{~s}, 55^{\circ} \mathrm{C}$ for $40 \mathrm{~s}$, and $72^{\circ} \mathrm{C}$ for $60 \mathrm{~s}$, with a final extension at $72^{\circ} \mathrm{C}$ for $10 \mathrm{~min}$. The amplified products were separated on $1 \%$ agarose gel and analyzed with Gene analysis software package (Gene Company).

\section{Results and Discussion}

Cloning of grape berry PLD $\alpha$ cDNA. By comparing amino acid sequences of PLD $\alpha$ family from Arabidopsis, castor bean, cabbage, tobacco, cowpea and tomato, two consensus regions (NAKHLIYITGW and NINQRSMDGAR) were selected to design degenerate primers that were given in Fig. 1. RT-PCR was carried out using designed degenerate primers and fruit cDNAs from grape berries, and one $1.4 \mathrm{~kb}$ DNA fragment was amplified, cloned into the in pGEM-T Easy vector and sequenced. Blast search of GenBank revealed that this fragment shared $83.6 \%$ identity with the corresponding sequence of Ricinus Commuis PLD ( $\underline{\mathbf{L 3 3 6 8 6}}$ ) and was, therefore, considered to be a cDNA fragment of $P L D \alpha$. Genespecific primers were generated for conducting rapid amplification of cDNA end (RACE) using this $1.4 \mathrm{~kb}$ fragment. The products from 3'- and 5'-RACE were purified and cloned. After PCR and Enzyme digestion confirmation, both products were sequenced. By comparing and aligning the sequences of the 3'- and 5'-RACE products, a $2627 \mathrm{bp}$ fulllength cDNA sequence of $P L D \alpha$ from grape berries was

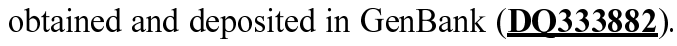




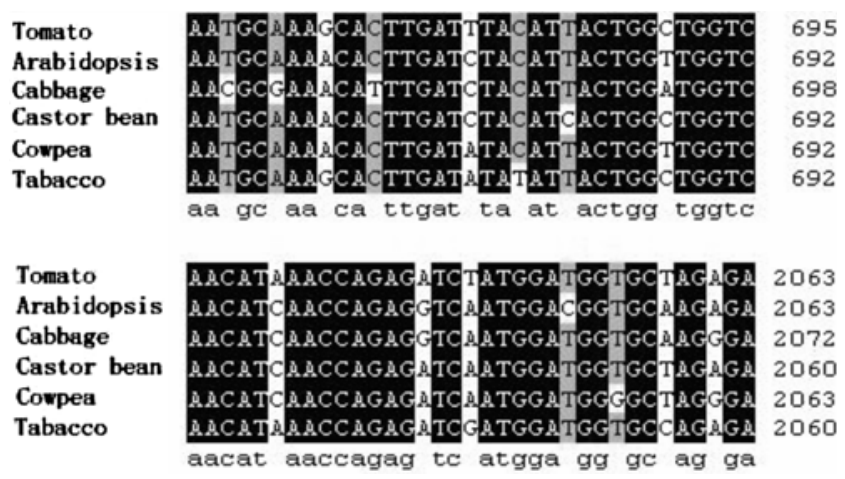

Fig. 1. Alignment of nucleotide sequences of PLD $\alpha$ for the generation of RT-PCR degenerate primers. Forward primer (5'AAT GCA AAR CAC TTG ATH TAC ATT ACT GGY TGG TC-3') was corresponding to the amino acid sequence NAKHL IYITGW and reverse primer (5'-TCT NGC ACC ATC CAT TGA TCT CTG GTT KAT GTT-3') corresponding to the amino acid sequence NINQRSMDGAR. During the degenerate primers, $\mathrm{R}=\mathrm{A}$ or $\mathrm{G}, \mathrm{H}=\mathrm{A}$ or $\mathrm{T}$ or $\mathrm{C}, \mathrm{Y}=\mathrm{C}$ or $\mathrm{T}, \mathrm{N}=\mathrm{A}$ or $\mathrm{T}$ or $\mathrm{C}$ or $\mathrm{G}, \mathrm{K}=\mathrm{G}$ or $\mathrm{T}$.

Characteristics and predicted proterties of grape PLD $\alpha$. The isolated grape $P L D$ cDNA includes an open reading frame (ORF), beginning at $\mathrm{ATG}_{1}$ and ending at $\mathrm{TGA}_{2430}$, and a 3 ' non-coding region of $197 \mathrm{bp}$. The 2430-nucleotides ORF encodes a putative protein of 809 amino acid residues, with a calculated molecular mass of $91.8 \mathrm{KDa}$ and an isoelectric point (pI) value of 5.58 (ExPASy, ProtParam tool). A database search with BLASTp 2.2.13 (National Center for Biotechnology Information databases) showed the sequence homology of grape berry PLDo, is $84.7 \%$ identity to that of castor bean

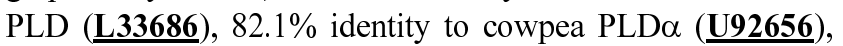
$81.1 \%$ identity to tobacco PLD ( $\underline{\mathbf{Z 8 4 8 2 2}}$ ), 80.7\% identity to PLD $\alpha$ from strawberry (AY758359) and $80.4 \%$ identity to PLD $\alpha$ from cherry tomato fruit ( $\underline{\mathbf{A F 2 0 1 6 6 1}})$. But sequence homology to the other isoforms of PLD, PLD beta (Arabidopsis, $\underline{\mathbf{U 8 4 5 6 8}}$ ) and PLD gamma (Arabidopsis, $\underline{\mathbf{A F 0 2 7 4 0 8}}$ ) is $43.9 \%$ and $40.6 \%$, respectively. The multiple sequence alignment of grape berry PLD $\alpha$ with many other PLDas from higher plants by CLUSTAL $\mathrm{X}$ was shown in Fig. 2, and the phylogenic trees (Fig. 3) were generated by using Clustal X and Bootstrap method. All these results showed the grape PLD $\alpha$ had high identity with other plant PLDos at the amino acid level, indicating the grape PLD reported in this paper was a member of PLD $\alpha$ superfamily.

Secondary structure predictions for grape PLD $\alpha$. From the predicted amino acid sequence for grape PLD, structural and functional properties were detected using NCBI Conserved Domain Database (Marchler-Bauer and Bryant, 2004). The result (Fig.4) displayed three conserved domains, the C2_2 domain (protein kinase $\mathrm{C}$ conserved region 2, subgroup 2) and two PLDc domains (phospholipase D active site motifs), which were also present in other plant PLDs. The distinction between PLD alpha, beta and gamma is based on the differences in the calcium-binding capacity of $\mathrm{C} 2$ domains and the properties of the two active site motifs (Wang, 1999).

The $\mathrm{C} 2$ domain has been identified in a number of enzymes such as phospholipases and protein kinase C (Ponting et al., 1996; Nalefski et al., 1997). The proteins that comprise C2 domain can bind with cell membrane in a calcium-dependent manner (Wang, 2000) and such binding is coordinated by four to five amino acid residues present in two bipartite loops of this domain (Ponting et al., 1996). In the grape PLDo, C2 domain begins at around at aa 9 and ends at around aa 148 near the N-terminus (from NCBI conserved region blast). Secondary structure prediction was conducted through PSIPRED (Altschul et al., 1997), indicating the C2 domain was constituted by eight beta strand motifs (Fig. 5). This is consistent with previous report that the $\mathrm{C} 2$ domain forms an eight-stranded anti-parallel beta sandwich (Kopka et al., 1998).

The PLDc domains were considered the catalytic domains of plant PLD, for the containing of highly conserved HxKxxxxD motifs, which can be used to define to PLD superfamily (Ponting et al., 1996; Sung et al., 1997). Now evidence has shown the catalytic regions of PLD also interact with $\mathrm{Ca}^{2+}$ binding (Pappan et al., 2004). In grape berry PLD $\alpha$, the first active site having the amino acids HQKIVVVD is located at the 331-338 amino acids; the second active site is located further downstream comprising amino acids 660-667 with the sequence HAKMMIVD. The two HKD motifs are separated by about 320 amino acids in the primary structure. In the HKD motifs, the conserved aspartate, lysine and histidine form a catalytic triad, which catalyses the hydrolysis or formation of phosphodiester bonds (Gottlin et al., 1998). Point mutagenesis of PLD from several species has revealed that these amino acids are critical for catalysis in vitro and for PLD function in vivo (Gottlin et al., 1998). Detailedly, the aspartate residue acts as a nucleophile and attacks the scissile bond forming a covalent acyl-substrate intermediate, the positively charged lysine is involved in substrate binding possibly through interaction with positively charged phosphate groups, and the histidine stabilizes the carboxylate anion (Gottlin et al., 1998).

Close to the second $\mathrm{H} \times \mathrm{K} \times \times \times \times \mathrm{D}$ motif, there is a highly conserved sequence of IGSANINQR of which an invariant serine residue has been proposed to be the nucleophile that attacks the phosphorus atom of the substrate phospholipids (Sung et al., 1997).

Southern blot analysis. To determine the copy number of the $P L D$ gene in the genome, grape genomic DNA was digested with two restriction enzymes (EcoRI and $X b a \mathrm{I})$, and hybridized with a grape $P L D$ cDNA fragment as probe. Southern blot analysis (Fig. 6) showed that only one or two copies were recognized at high-stringency conditions, indicating that the grape $P L D$ gene maybe belonged to a small gene family. This is similar to previous reports about low copies of 


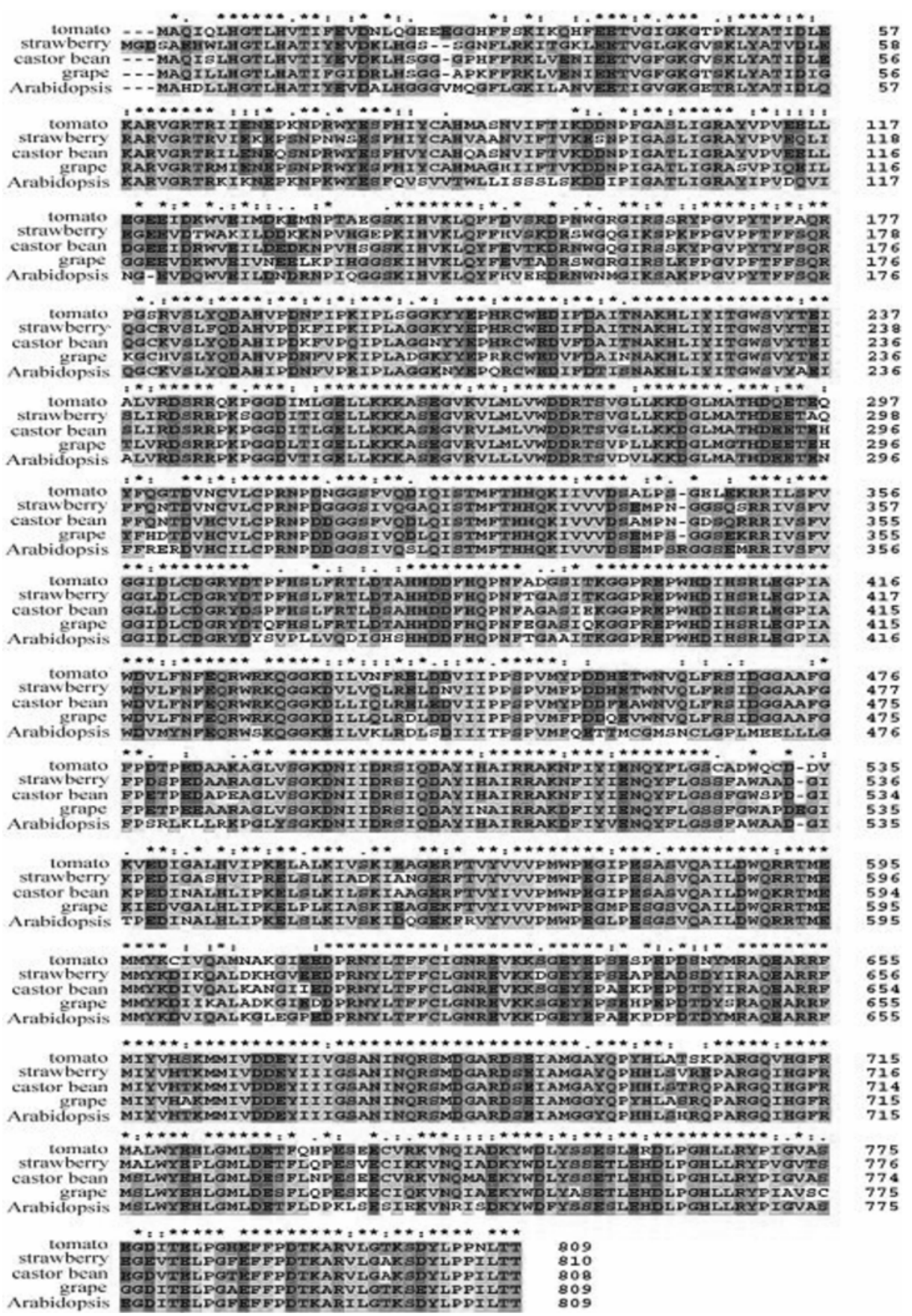

Fig. 2. Multiple alignment of the deduced amino acid sequences of $P L D \alpha$ gene from grape (GenBank accession number $\mathbf{D Q 3 3 3 8 8 2}$ ),

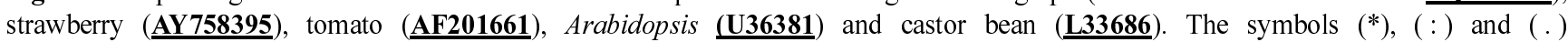
represented completely identical, conservative and semi-conservative amino acid residues respectively.

PLD genes in cowpea (Maarouf et al., 1999) and in peanut (Guo et al., 2005). These individual PLDs in the cell may be activated differently, hydrolyze different lipid species, and have unique functions (Welti et al., 2002).

Changes of phospholipase $D$ activity during heat acclimaiton. To analyze the role of PLD in heat-activated signal transduction in grape berries, we measured PLD activity in response to heat acclimation. PLD activity in vivo was determined by the release of ${ }^{3} \mathrm{H}$-choline into the reaction system. As shown in Fig. 7, PLD activity was induced after $0.5 \mathrm{~h}$ of incubation at $38^{\circ} \mathrm{C}$. The maximum activity was attained at $1 \mathrm{~h}$ after heat acclimation, which level was 1.65fold increase compared to the control. And then PLD activity decreased rapidly after $2 \mathrm{~h}$ of treatment. It is a typical characteristic of signal molecular that PLD activity increased 


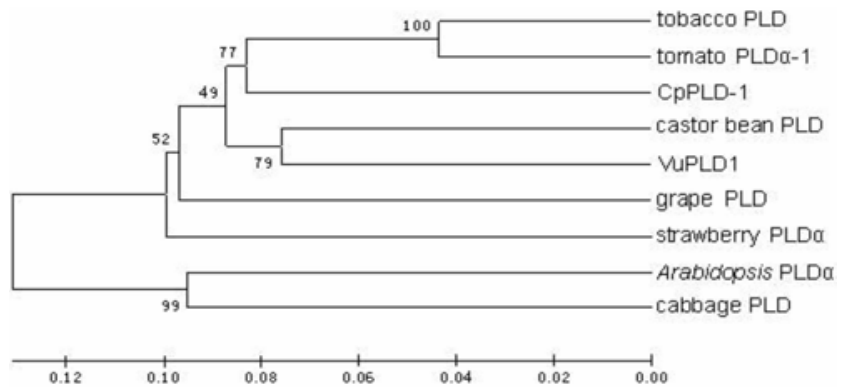

Fig. 3. Phylogentic relationship between various PLD $\alpha$. The tree was constructed from amino acid sequences of PLD $\alpha$. Accession numbers for these sequences are as follows: grape PLD

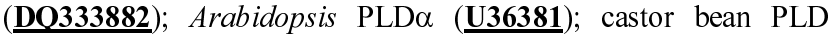

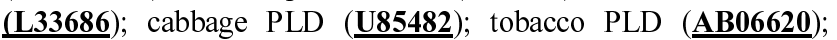

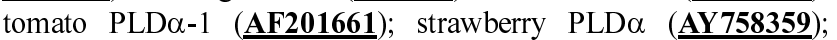

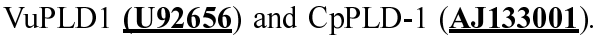

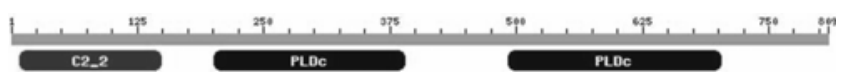

Fig. 4. Putative conserved domains in grape protein PLD have been detected by searching the conserved domain (CD) database. The predicted amino acid sequence of PLD is drawn as a gray bar, with a ruler indicating its length. The balloons below the gray bar represent the individual hits of CDs in the CD database. The CD short names are printed in the domain-balloons. C2 2 domain (Ochoa et al., 2001), protein kinase C conserved region 2 , subgroup 2, is present in phospholipase, protein kinases $\mathrm{C}$ and synaptotagmins as $\mathrm{Ca}^{2+}$-binding motif; PLDc, Phospholipase D active site motifs (Stuckey and Dixon 1999), hydrolyze the terminal phosphodiester bond of phospholipids to phosphatidic acid and a hydrophilic constituent.

and decreased rapidly. Increase in PLD activity was also noticeable in some stress system, for instance, activation of PLD was an early response to cold exposure in Arabidopsis suspension cells (Ruelland et al., 2002). High PLD activity could hydrolyze phospholipids drastically to phosphatidic acid (PA) which is the second message during stress signal transduction, under freezing (Welti et al., 2002) and osmotic stress (Munnik et al., 2000; Zonia and Munnik, 2004).

Expression of phospholipase D induced by heat acclimation. To investigate whether the heat-activated activity is linked to the expression of of phospholipas $\mathrm{D}$, the grape tissues at different pre-incubation time $\left(38^{\circ} \mathrm{C} 0,0.5,1,2,4,8,12 \mathrm{~h}\right)$ were analyzed by Western blot and RT-PCR. Meanwhile, the expression of HSP73 was assayed as a direct indicator of heat acclimation. The production of heat shock proteins is the bestcharacterized aspect of acquired thermotolerance (Vierling et al., 1991; Larkindale et al., 2005).

Western blot analyses (Fig. 8A) of total proteins from heat treatments showed the corresponding changes with PLD activity. The PLD $\alpha 1$ antibody against the Arabidopsis PLD $\alpha 1$ protein reacted with a band at $92 \mathrm{KDa}$, which corresponds to the molecular mass of the protein deduced from grape $P L D \alpha$

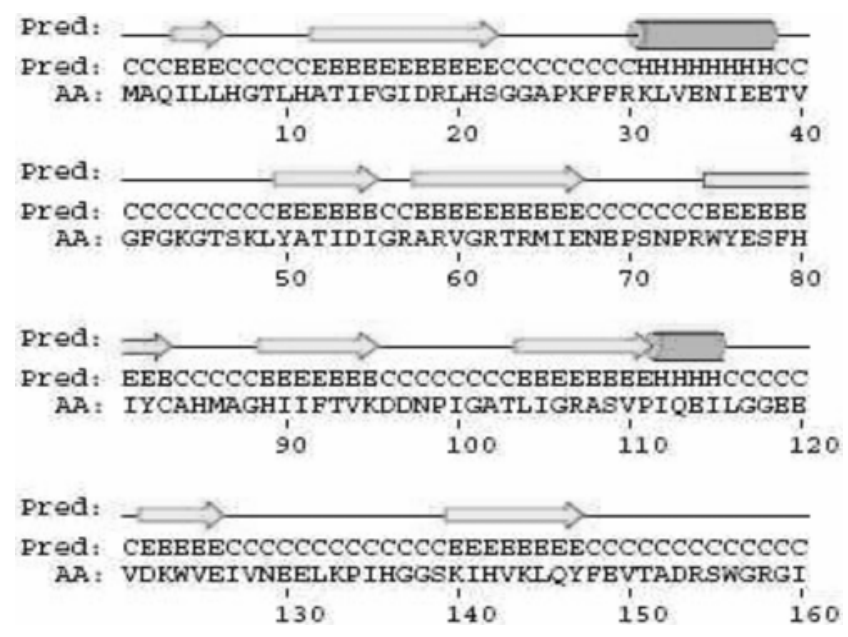

Fig. 5. Predicted amino acid sequence and secondary structure probabilities for grape PLD C2 domain which comprises amino acid 9-148. The secondary structure probabilities were obtained through PSIPRED. H, helix; E, beta strand; C, coil.

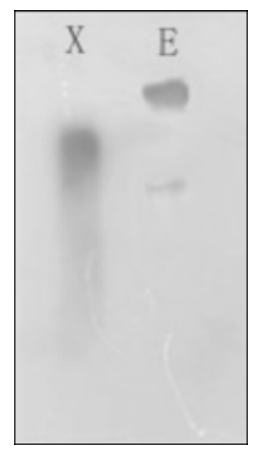

Fig. 6. Southern blot analysis of genomic DNA for PLD gene of grape berry. Genomic DNA $(30 \mu \mathrm{g})$ from grape berries was cut by $E c o R$ I (E) and Xba I (X). Southern blot was hybridized with one conserved cDNA fragment of grape $P L D$ and the membrane was washed under high stringency condition.

gene. PLD protein already increased at $0.5 \mathrm{~h}$ after incubation, reaching a maximum at $1 \mathrm{~h}$ before decreasing to the control level. This indicated that the synthesis of new PLD protein in grape berry tissues was induced by heat acclimation and the changes in PLD activity corresponded to that of the PLD polypeptide amounts. During the PLD mRNA accumulation analysis, seven cDNA clones that derived from the treated grape berry were selected. Actinl gene, expected to show a constitutive expression pattern, was used as the internal control. RT-PCR analyses (Fig. 8B) showed that in tissues from control $\left(38^{\circ} \mathrm{C} 0 \mathrm{~h}\right)$, the $P L D$ gene is expressed at low level. When grape berries were submitted to heat acclimation, the PLD transcript levels showed fast activation at $0.5 \mathrm{~h}$, indicating that the transcription of $P L D$ gene was enhanced by heat acclimation.

As shown in Fig. 9A, the expression of HSP73 was greatly induced between $0.5 \mathrm{~h}$ and $4 \mathrm{~h}$. This may be an aspect of the 


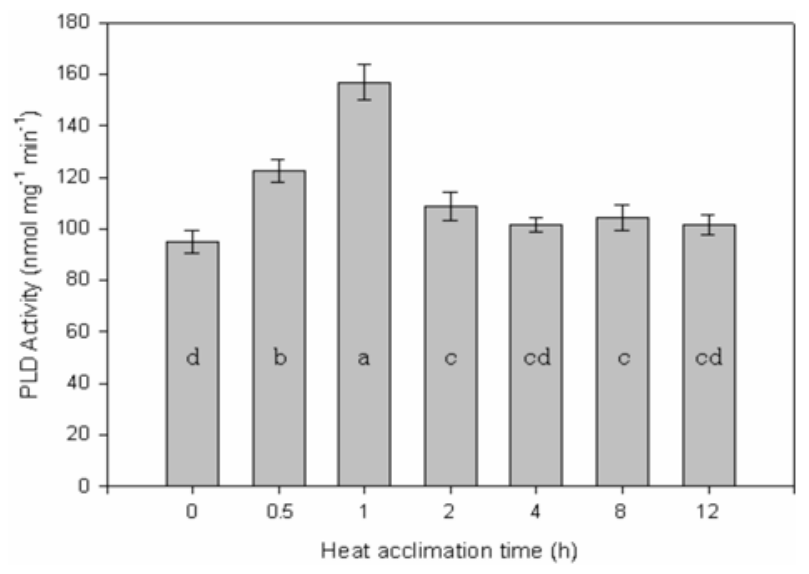

Fig. 7. Changes of PLD activity of grape berries under heat acclimation $\left(38^{\circ} \mathrm{C}\right)$. PLD activity was assayed in the presence of $100 \mathrm{mM}$ Mes/Tris (pH 6.5), $25 \mathrm{mM} \mathrm{CaCl}_{2}$ and $2 \mathrm{mM}$ egg yolk phosphatidylcholine with $1.85 \mathrm{KBq}$ L-3-Phosphatidyl[N-methyl$\left.{ }^{3} \mathrm{H}\right]$ choline, 1,2-dipalmitoyl. Values are mean \pm S.E. from three separate experiments. Different letters indicate a statistical difference at $P \leq 0.05$ among treatments according to Duncan's multiple range test.

reason that heat acclimation can improve the heat tolerance of plants. When grape berries were pretreated by 1-butanol, the expression of HSP73 under heat acclimation can be inhibited obviously (Fig. 9B). 1-Butanol is a useful inhibitor of PLDdependent production of the signaling molecule phosphatidic acid (PA). The alcohol can be used as a trans-phosphatidylation substrate, resulting in the formation of phosphatidylbutanol, which has no known biological activity (Munnik et al., 1995). So this experiment provided direct evidence that PLD was involved during heat acclimation. But the mechanism and the signal transduction during heat acclimation are not known much.

As a new family of phospholipases, PLD has been involved in signal transduction and cell regulation in resent studies. For example, activation of PLD occurs in response to various biotic and abiotic stress cues, which include water stress (Frank et al., 2000), wounding (Ryu and Wang, 1996; Wang et al., 2000) and freezing (Li et al., 2004). But to now days, There is no paper to study the role of PLD during high temperature, though it was reported many years ago that PLD activity was regulated by several environmental factors such as heating, chilling and freezing. In this research, heat acclimation induced the accumulation of PLD mRNA and the synthesis of new PLD protein, and increased the activity at the early of heat treatment. Meanwhile the expression of HSP73 can be blocked by the pretreatments of berry tissues with the PLD activity inhibitor 1-butanol (Fig. 9). All these results showed phospholiapse D was involved in the signal transduction of heat acclimation, thus providing a link between PLD-mediated membrane phospholipid hydrolysis and the signaling of the plant response to heat acclimation or
(A)

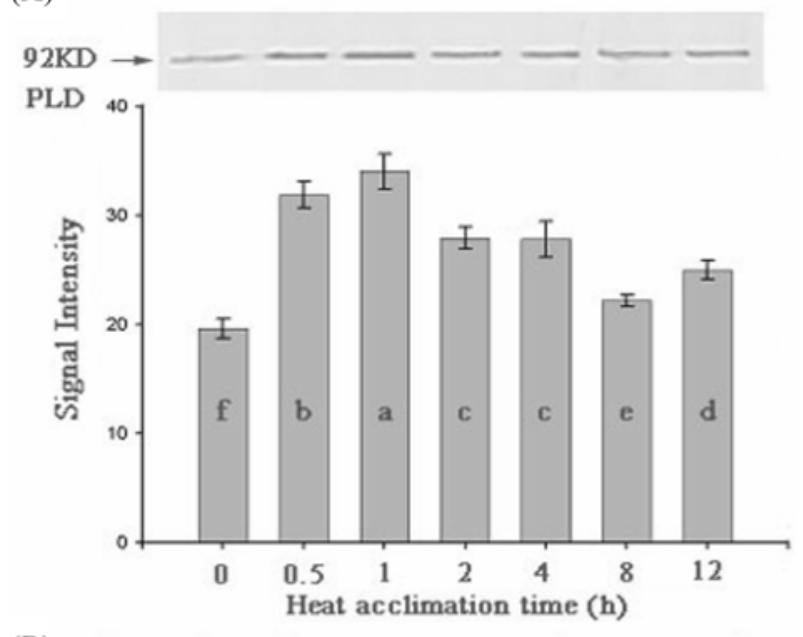

(B)
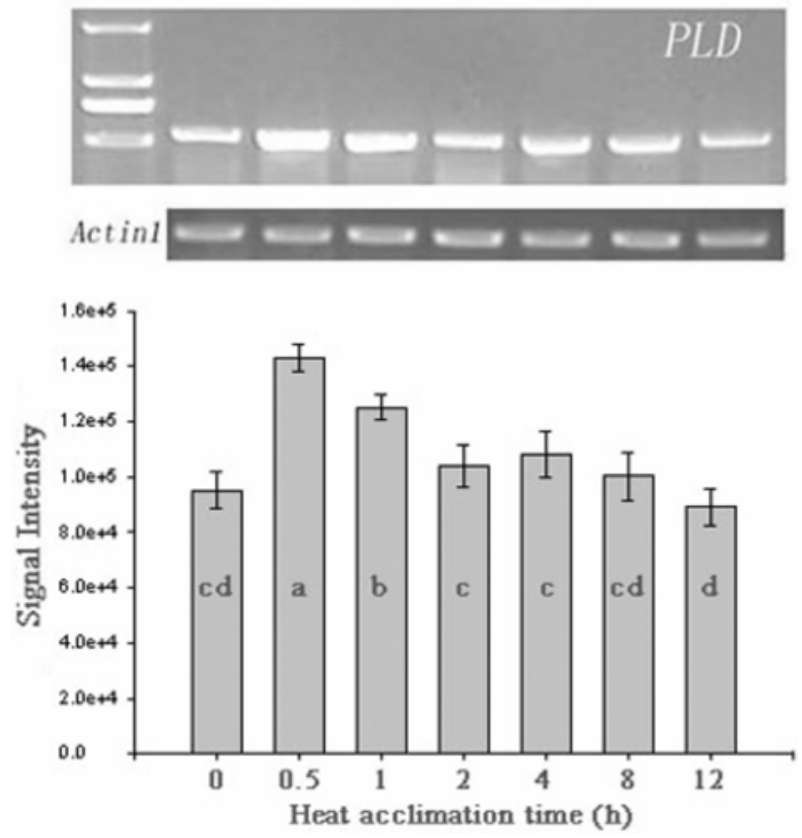

Fig. 8. Heat acclimation $\left(38^{\circ} \mathrm{C}\right)$ elevated the amounts of PLD (A) and induced the expression of PLD on the transcriptional level (B) in grape berry tissues. Protein extracts from grape berry tissues were separated on $10 \%(\mathrm{w} / \mathrm{v})$ SDS-polyacrylamide gels (10 $\mu \mathrm{g}$ protein/lane), transferred onto a nitrocellulose membrane, and probed with antibody against Arabidopsis PLD 1 followed by alkaline phosphatase detection. During the analysis of RTPCR, total RNA from grape berry tissues heat acclimation treated for $0,0.5,1,2,4,8$ and $12 \mathrm{~h}$ were reverse-transcribed in the presence of an oligo $\mathrm{d}(\mathrm{T})_{15}$ primer and PCR amplification was performed using PLD cDNA-specific primers. Meanwhile, Actinl was amplified as an internal control. The amplified products were separated on $1 \%$ agarose gel and analyzed with Gene analysis software package. The data of signal intensity in (A and B) are the means from three analyses of one of two independent replicates. Bars are standard errors $(n=3)$. Different letters indicate a statistical difference at $P \leq 0.05$ among treatments according to Duncan's multiple range test. 
(A)

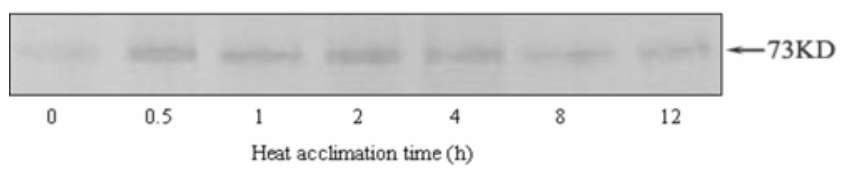

(B)

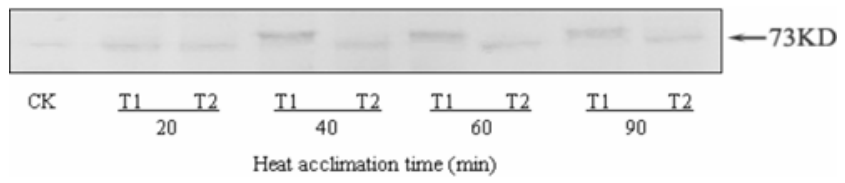

Fig. 9. Western blots of HSP73 isolated from grape berries: (A) heat acclimation $\left(38^{\circ} \mathrm{C}\right)$ elevated the amounts of HSP73; (B) 1butanol inhibited the expression of HSP73 under heat acclimation. Equal amounts of protein $(10 \mu \mathrm{g}$ protein/lane $)$ were subjected to SDS-PAGE, transferred onto a nitrocellulose membrane, and probed with antibody against HSP73 followed by alkaline phosphatase detection. The grape berries were used in (B) for the following treatment: CK, without heat acclimation; $\mathrm{T} 1$, heat acclimation at $38^{\circ} \mathrm{C}$ for $20,40,60$ and $90 \mathrm{~min}$; $\mathrm{T} 2$, pretreatment with $0.1 \%(\mathrm{v} / \mathrm{v})$ 1-butanol for $30 \mathrm{~min}$ followed by heat acclimation at $38^{\circ} \mathrm{C}$ for $20,40,60$ and $90 \mathrm{~min}$.

heat stress. The response is similar to the heat acclimation induced expression of gene involved in PLC signaling in pea plant (liu et al., 2006). In the PLC and PLD pathways, plants could adapt to heat stress, making them more tolerant to environment. More researches such as the mechanism of phospholipase D to influence the thermotolerance are under work.

Acknowledgements This work was supported by Grant Nos. 30471192 and 30671468 from the National Natural Science Foundation of China. We also thank Dr. Xuemin Wang (University of Missouri-St. Louis, USA) for kindly providing us with PLD $\alpha 1$ antibody, and Dr. Wenhua Zhang (Nanjing Agricultural University, China) and Dr. G. Paliyath (University of Guelph, Canada) for the helpful advices.

\section{References}

Altschul, S. F., Madden, T. L., Schaffer, A. A., Zhang, J., Zhang, Z., Miller, W. and Lipman, D. J. (1997) Gapped BLAST and PSI BLAST: a new generation of protein database search programs. Nucleic Acids Res. 25, 3389-3402.

Beruter, J. and Studer, F. M. (1995) Comparison of sorbitol transport in excised tissue discs and cortex tissue of intact apple fruit. $J$. Plant Physiol. 146, 95-102.

Bradford, N. M. (1976) A rapid and sensitive method for the quantitation microgram quantities of protein utilizing the principle of protein-dye bingding. Anal. Biochem. 72, 248-259.

Dhindsa, R. S., Plumb-Dhindsa, P. and Thorpe, T. A. (1981) Leaf senescence: correlated with increased leaves of membrane permeability and lipid peroxidation and decreased levels of superoxide dismutase and catalase. J. Exp. Bot. 32, 93-101.
Dyer, J. H., Zheng, L. and Wang, X. M. (1995) Cloning and nucleotide sequence of a cDNA encoding phospholipase D from Arabidopsis (Accession No. U36381). Plant Physiol. 109, 1497.

Famiani, F., Walker, R. P., Tecsi, L., Chen, Z. H., Proietti, P. and Leegood, R. C. (2000) An immunohistochemical study of the compartmentation of metabolism during the development of grape berries. J. Exp. Bot. 51, 675-683.

Frova, C. (2000) Genetic dissection of thermotolerance in maize; in Physical Stress in Plants, Grillo, S. and Leone, A. (eds.), pp.3138, Springer-Verlag, New York, USA

Gottlin, E. B., Rudolph, A. E., Zhao, Y., Matthews, H. R. and Dixon, J. W. (1998) Catalytic mechanism of the phospholipase D superfamily proceeds via a covalent phosphohistidine intermediate. Proc. Natl. Acad. Sci. USA 95, 9202-9207.

Gradiner, J. C., Harper, J. D., Weerakoon, N. D., Collings, D. A., Ritchie, S., Gilroy, S., Cyr, R. J. and Marc, J. (2001) A 90-KD phospholipase $\mathrm{D}$ from tobacco binds to microtubules and the plasma membrane. Plant Cell 13, 2143-2158.

Guo, B. Z., Xu, G., Cao, Y. G. and Holbrook, C. C. (2005) Identification and characterization of phospholipase $\mathrm{D}$ and its association with drought susceptibilities in peanut (Arachis hypogaea). Planta 223, 512-520.

Howarth, C. J. and Ougham, H. J. (1993) Gene expression under temperature stress. New Phytol. 125, 1-26.

Isla, M. I., Vattuone, M. A. and Sampietro, A. R. (1998) Essential group at the active site of Frapaeolum invertase. Phytochemistry 47, 1189-1193.

Kopka, J., Christophe, P., Alistair, M. H. and Bernd, M. R. (1998) $\mathrm{Ca}^{2+} /$ phospholipid-binding (C2) domain in multiple plant proteins: novel components of the calcium-sensing apparatus. Plant Mol. Biol. 36, 627-637.

Laemmli, U. K. (1970) Cleavage of structural protein during the assembly of the head of bacteriophage T4. Nature 227, 680-685.

Larkindale, J., Hall, J. D., Knight, M. R. and Vierling, E. (2005) Heat stress phenotypes of Arabidopsis mutants implicate multiple signaling pathways in the acquisition of thermotolerance. Plant Physiol. 138, 88-897.

Larkindale, J. and Huang, B. R. (2004) Thermotolerance and antioxidant systems in Agrostis stolonifera: Involvement of salicylic acid, abscisic acid, calcium, hydrogen peroxide, and ethylene. J. Plant Physiol. 161, 405-413.

Levitt, J. (1980) Responses of plants to environmental stresses; in Physiological Ecology, Kozlowski, T. T. (ed.), pp. 347-448, Academic Press, New York, USA

Li, W. Q., Li, M. Y., Zhang, W. H., Welti, R. and Wang, X. M. (2004) The plasma membrane-bound phospholipase Dä enhances freezing tolerance in Arabidopsis thaliana. Nature Biotech. 22, 427-433.

Liu, H. T., Huang, W. D., Pan, Q. H., Weng, F. H., Zhan, J. C., Liu, Y., Wan, S. B. and Liu, Y. Y. (2006) Contributions of PIP $_{2^{-}}$ specific-phospholipase $\mathrm{C}$ and free salicylic acid to heat acclimation-induced thermotolerance in pea leaves. J. Plant Physiol. 163, 405-416.

Maarouf, H. E., Zuily-Fodil, Y., Gareil, M., d'Arcy-Lameta, A. and PhamThi, A. T. (1999) Enzymatic activity and gene expression under water stress of phospholipase D in two cultivars of Vigna unguiculata L. Walp. Differing in drought tolerance. Plant Mol. Biol. 39, 1257-1265.

Marchler-Bauer, A., Anderson, J. B., Cherukuri, P. F., DeWeeseScott, C., Geer, L. Y., Gwadz, M., He, S., Hurwitz, D. I., 
Jackson, J. D., Ke, Z., Lanczycki, C. J., Liebert, C. A., Liu, C., Lu, F., Marchler, G. H., Mullokandov, M., Shoemaker, B. A., Simonyan, V., Song, J. S., Thiessen, P. A., Yamashita, R. A., Yin, J. J., Zhang, D. and Bryant, S. H. (2005) CDD: a conserved domain database for protein classification. Nucleic Acids Res. 33, 192-196.

Marchler-Bauer, A. and Bryant, S. H. (2004) CD-Search: protein domain annotations on the fly. Nucleic Acids Res. 32, 327-331.

Munnik, T., Arisz, S. A., de Vrije, T. and Musgrave, A. (1995) G protein activation stimulates phospholipase $\mathrm{D}$ signaling in plants. Plant Cell 7, 2197-2210.

Munnik, T., Meijer, H., Riet, B., Hirt, H., Frank, W., Bartels, D. and Musgrave, A. (2000) Hyperosmotic stress stimulates phospholipase D activity and elevates the levels of phosphatidic acid and diacylglycerol pyrophosphate. Plant J. 22, 147-154.

Nalefski, E. A., Slazas, M. M. and Falke, J. J. (1997) Calcium signaling cycle of a membrane docking $\mathrm{C} 2$ domain. Biochemistry 36, 12011-12018.

Ochoa, W. F., Garcia-Garcia, J., Fita, I., Corbalan-Garcia, S., Verdaguer, N. and Gomez-Fernandez, J. C. (2001) Structure of the $\mathrm{C} 2$ domain from novel protein kinase Cå. A membrane binding model for $\mathrm{Ca}^{2+}$-independent $\mathrm{C} 2$ domains. J. Mol. Biol. 311, 837-849.

Pan, Q. H., Zhan, J. C., Liu, H. T., Zhang, J. H., Chen, J. Y., Wen, P. F. and Huang, W. D. (2006) Salicylic acid synthesized by benzoic acid 2-hydroxylase participates in the development of thermotolerance in pea plants. Plant Sci. 171, 226-233.

Pappan, K., Zheng, L., Krishnamoorthi, R. and Wang, X. M. (2004) Evidence for and characterization of $\mathrm{Ca}^{2+}$ binding to the catalytic region of Arabidopsis thaliana phospholipase Dâ. J. Biol. Chem. 279, 47833-47839.

Pinhero, R. G., Almquist, K. C., Novotna, Z. and Paliyath, G (2003) Developmental regulation of phospholipase D in tomato fruits. Plant Physiol. Bioch. 41, 223-240.

Pinhero, R. G., Paliyath, G., Yada, R. Y. and Murr, D. P. (1998) Modulation of phospholipase $\mathrm{D}$ and lipoxygenase activities during chilling. Relation to chilling tolerance of maize seedlings. Plant Physiol. Biochem. 36, 213-224.

Ponting, C. P. and Kerr, I. D. (1996) A novel family of phospholipase D homologues that includes phospholipid synthesis and putative endonucleases. Protein Sci. 5, 914-922.

Rogers, S. O. and Bendlich A. L. (1994) Extraction of total cellular DNA from plants, algae and fungi; in Plant Molecular Biology Manual, Gelvin, S. B. and Schilperoort, A. R. (eds), pp. 1-8, Kluwer Academic Publishers, Dordrecht, Netherland.

Ruelland, E., Cantrel, C., Gawer, M., Kader, J. C. and Zachowski, A. (2002) Activation of phospholipase C and D is an early response to a cold exposure in Arabidopsis suspension cells. Plant Physiol. 130, 999-1007.

Ryu, S. B. and Wang, X, M. (1996) Activation of phospholipase D and the possible mechanism of activation of wound-induced lipid hydrolysis in castor bean leaves. Biochim. Biophys. Acta 1303, 243-250.

Sang, Y. M., Zheng, S. Q., Li, W. Q., Huang, B. R. and Wang, X. M. (2001) Regulation of plant water loss by manipulating the expression of phospholipase D $\alpha$. Plant J. 28, 135-144.
Srikanthbabu, V., Ganeshkumar, Krishnaprasad, B. T., Gopalakrishna, R., Sayitha, M. and Udayakumar, M. (2002) Identification of pea genotypes with enhanced the thermotolerance using temperature induction response technique (TIR). J. Plant Physiol. 159, 535-545.

Stuckey, J. A. and Dixon, J. E. (1999) Crystal structure of a phospholipase D family member. Nat. Struct Biol. 6, 278-284.

Sung, D. Y., Kaplan, F., Lee, K. J. and Guy, C. L. (2003) Acquired tolerance to temperature extremes. Trends Plant Sci. 8, 179-187.

Sung, T., Roper, P. L., Zhang, Y., Rudge, S. A., Temel, R., Moss, B., Engebrecht, J. and Frohman, M. A. (1997) Mutagenesis of phospholipase D defines a superfamily including a trans-golgi, viral protein required for poxvirus pathogenicity. $E M B O J .16$, 4519-4530.

Vierling, E. (1991) The roles of heat shock proteins in plants. Plant Mol. Biol. 42,519-620.

Wang, C. X., Zien, C. A., Afitlhile, M., Welti, R., Hildebrand, D. F. and Wang X. M. (2000) Involvement of phospholipase D in wound-induced accumulation of jasmonic acid in Arabidopsis. Plant Cell 12, 2237-2246.

Wang, L. J., Huang, W. D., Li,, J. Y., Liu, Y. F. and Shi, Y. L. (2004) Peroxidation of membrane lipid and $\mathrm{Ca}^{2+}$ homeostasis in grape mesophyll cells during the process of cross-adaptation to temperature stresses. Plant Sci. 167, 71-77.

Wang, L. J. and Li, S. H. (2006) Salicylic acid-induced heat or cold tolerance in relation to $\mathrm{Ca}^{2+}$ homeostasis and antioxidant systems in young grape plants. Plant Sci. 170, 685-694.

Wang, X. M. (1999) The role of phospholipas D in signaling cascades. Plant Physiol. 120, 645-651.

Wang, X. M. (2000) Multiple forms of phospholipase D in plants: The gene family, catalytic and regulatory properties, and cellular functions. Prog. Lipid Res. 39, 109-149.

Wang, X. M. (2004) Lipid signaling. Curr. Opin. Plant Biol. 7, 329336.

Wang, X. M., Dyer, J. H. and Zheng, L. (1993) Pruification and immunological analysis of phospholipase D from castor bean endosperm. Arch. Biolchem. Biophys. 306, 386-394.

Wang, X. M., Xu, L. W. and Zheng, L. (1994) Cloning and expression of phosphatidylcholine-hydrolyzing phospholipase D from Ricinus communis L. J. Biol. Chem. 269, 20312-20317.

Welti, R., Li, W. Q., Li, M. Y., Sang, Y. M., Biesiada, H., Zhou, H., Rajashekar, C. B., Williams, T. D. and Wang, X. M. (2002) Profiling membrane lipids in plant stress responses: role of phospholipase Dá in freezing-induced lipid changes in Arabidopsis. J. Biol. Chem. 277, 31994-32002.

Wen, P. F., Chen, J. Y., Kong, W. F., Pan, Q. H., Wan, S. B. and Huang, W. D. (2005) Salicylic acid induced the expression of phenylalanine ammonia-lyase gene in grape berry. Plant Sci. 169, 928-934.

Zhang, J. H., Huang W. D., Pan Q. H. and Liu Y. P. (2005) Improvement of chilling tolerance and accumulation of heat shock proteins in grape berries (Vitis vinifera cv. jingxiu) by heat pretreatment. Postharvest Biol. Tec. 38, 80-90.

Zonia, L. and Munnik, T. (2004) Osmotically induced cell swelling versus cell shrinking elicits specific changes in phospholipid signals in tobacco pollen tubes. Plant Physiol. 134, 813-823. 